\title{
LONGE DE CASA: MINHA JORNADA E HISTÓRIAS DE REFUGIADOS PELO MUNDO
}

ESTANTE

DE LIVROS livro Longe de casa: minha jornada e histórias de refugiadas pelo mundo, de autoria de Malala Yousafzai e Liz Welch, é um relicário de histórias de vida de mulheres refugiadas e suas famílias. Trata-se de um livro biográfico, que nesta resenha utilizo como pano de fundo para refletir sobre resiliência pessoal e familiar.

Malala Yousafzai, refugiada paquistanesa, ficou mundialmente conhecida por ser ganhadora do Prêmio Nobel da Paz, em 2014. A honrosa premiação recebida deu-se por seu ativismo em prol dos direitos ao ensino de crianças e jovens paquistanesas, especialmente meninas, que no período de 2003 a 2009 foram proibidas pelo Talibã de frequentar a escola. Seu ativismo tornou-a alvo do Talibã e em 2012 sofreu um atentado enquanto se dirigia para a escola. Malala e sua família tornaram-se refugiados e mudaram-se forçosamente para o Reino Unido. Atualmente Malala estuda na Universidade de Oxford, alcançando seu sonho de criança de estudar.

As narrativas de Malala, Zaynab, Sabreen, Muzoon, Najla, María, Analisa, Marie Claire, Ajida e Farah representam as milhares de pessoas que são obrigadas a deixar sua casa, história, cultura e relações. Trata-se de vidas marcadas por sofrimento, perseguição, violência, medos, rupturas e traumas. Em contextos de refúgio, não é uma escolha migrar. É, talvez, a única possibilidade de sobrevivência.

O Alto Comissionado das Nações Unidas (ACNUR), agência da Organização das Nações Unidas (ONU) para Refugiados, estimava que, em 2017, eram 68,5 milhões de pessoas em condição de refúgio em todo o mundo, dado este que já ultrapassou a marca dos 70 milhões (ACNUR, 2018). São pessoas sozinhas ou famílias inteiras necessitadas de uma nova oportunidade de vida e desejos de viver em/na paz.

"Quando minha família foi do Paquistão para Birmingham, levou apenas a roupa do corpo. Não havia tempo para passar em casa, nem seria seguro. O que significava que tínhamos que começar do zero em um mundo que nos era totalmente estrangeiro." (Relato de Malala, p. 47).

$\mathrm{Na}$ medida em que conflitos civis ou calamidades ambientais acontecem (cito como exemplo o ocorrido em Moçambique em março de 2019), novos fluxos de pessoas deslocadas de seu país se constituem ao redor do mundo - sejam elas imigrantes ou refugiadas. Essas pessoas chegam aos países, estados e cidades e acionam novas demandas de atendimento para os diferentes profissionais e serviços.
ANA PAULA RISSON

Programa de PósGraduação em Psicologia, da Universidade Federal de Santa Catarina - UFSC, Florianópolis/SC, wBrasil 
$\mathrm{O}$ atendimento e acolhimento de demandas de refugiados requer uma postura profissional que inclua a história de vida antes da chegada ao novo local. Assim, atender e acolher estas histórias de destruição, dificuldades e reconstrução pela perspectiva da resiliência familiar nos possibilita, como profissionais, identificar as estratégias construídas pelas famílias diante do fenômeno de refúgio. Ao acolhermos estas histórias com olhar sistêmico, auxiliamos seus autores a ressignificá-las.

Dentre os teóricos que contribuem para pensarmos resiliência familiar, encontra-se Froma Walsh, que define o conceito como "o potencial para recuperação, reparo e crescimento nas famílias que enfrentam sérios desafios na vida" (Walsh, 2016, p. 399). Para a autora, os estressores podem desviar o funcionamento de um sistema familiar, com consequências diversas para os membros e relações. Assim, “a resposta da família é vital: os processos-chave na resiliência possibilitam que o sistema familiar se recupere em momentos difíceis para suavizar o estresse, reduzir o risco de disfunção e apoiar a adaptação ideal" (p. 401).

Nas histórias das refugiadas e suas famílias, identifica-se que a resiliência familiar emerge a partir da destruição da casa e cidade, da morte de familiares, do processo de fuga, na vida nos acampamentos e campos de refugiados e na vida no novo país. Cada fenômeno destes impulsionou a família para forçosas tomadas de decisões e reorganização, que na maioria das situações implica a sobrevivência.

"Eu queria uma vida melhor com toda a nossa família no Iêmen. Queria minha avó de volta. Eu sei que são sonhos impossíveis, mas posso realizar outros se acreditar em mim mesma e nos meus objetivos. Quero terminar os estudos para poder voltar ao meu lindo lar e levar justiça comigo. Quero reconstruí-lo. Acredito que toda história pode ter um final feliz, e eu vou criar esse final feliz para essa parte da minha história." (Relato de Zainab, p. 100)

Nos relatos das refugiadas do livro, identifica-se a saudade do lar (país de origem) e o desejo de poder retornar. Suas vidas e de suas famílias, agora em outro local e com mais segurança, seguem sendo um processo de adaptação e novos desafios, como: adaptação cultural, barreira linguística e regularização de documentação. Na perspectiva da resiliência familiar, torna-se imprescindível que a família compreenda e perceba suas capacidades de resposta diante de fatores estressores para identificar seu repertório de ações diante de novos desafios.

Malala, Zaynab, Sabreen, Muzoon, Najla, María, Analisa, Marie Claire, Ajida, Farah e suas famílias criaram, forçosamente e sem saber, estratégias resilientes de respostas frente a fatores estressores. Cada narrativa registrada no livro representa inúmeras outras que não receberam este espaço de visibilidade, mas que, certamente, precisaram enfrentar circunstâncias com essas características. 


\section{REFERÊNCIAS}

ACNUR - Alto Comissionado das Nações Unidas. (2017). ACNUR: número de pessoas deslocadas chega a 68,5 milhões em 2017.Acesso emhttps://nacoesunidas. org/acnur-numero-de-pessoas-deslocadas-chega-a-685-milhoes-em-2017/

Walsh, F. (2016). Resiliência familiar: resistência formada pela adversidade. In F. Walsh, Processos normativos da família: diversidade e complexidade. (pp. 399 - 427). Porto Alegre, RS: ArtMed Editora Ltda.

Yousafzai, M.\&Welch, L. (2019). Longe de casa: minha jornada e histórias de refugiadas pelo mundo. São Paulo, SP: Seguinte.

\section{ANA PAULA RISSON}

Psicóloga, mestra em Ciências da Saúde (Unochapecó) e doutoranda no Programa de Pós-Graduação em Psicologia da Universidade Federal de Santa Catarina - UFSC.

E-mail: annarisson@gmail.com 